Ann. Biol. anim. Bioch. Biophys., 1979, 19 (5), 1511-1520.

\title{
Ovarian follicular responsiveness and oocyte quality after gonadotrophic stimulation of mature pigs
}

by R. H. F. HUNTER,

School of Agriculture, University of Edinburgh, West Mains Road, Edinburgh, EH9 3JG, U. K.

Summary. The influence on the estrous cycle and ovulatory response of injecting pregnant mare serum and/or chorionic gonadotrophin has been examined in both the luteal and follicular phases. After a single injection of 1500 i.u. PMSG on Day 13 of the cycle, œstrus was expressed within five to seven days. By contrast, œstrus was delayed until Days 27 to 29 in six gilts injected similarly with PMSG on Day 14. Superovulation was not a characteristic of the response to PMSG injected in the late luteal phase. A single treatment with PMSG on Days 17, 18 or 19 slightly shortened the cestrous cycle and provoked superovulation in some of the animals, but treatment in the early follicular phase (Days 15 or 16) was considered the optimum time at which to initiate a superovulatory response. These observations correlate well with the incidence of ovarian compensatory hypertrophy after unilateral ovariectomy performed at different times during the follicular phase.

A small proportion of primary oocytes $(<10$ p. 100) was shed when superovulation followed Day 15 or 16 PMSG, and also after ovulation induced during the luteal phase, whereas up to 80 p. 100 primary oocytes were shed after injection of HCG on Day 17 ; such oocytes invariably underwent polyspermic penetration after artificial insemination. A fairly constant proportion of secondary oocytes (20-35 p. 100) could also be induced to undergo this form of abnormal fertilisation in several experimental situations, suggesting that the susceptibility to polyspermy in apparently mature eggs under specified conditions may be a means of revealing physiological incompetence and thus those eggs destined to undergo early embryonic death.

\section{Introduction.}

Following the discovery of the gonadotrophic hormones in the late 1920's, and the subsequent availability of crude hormonal preparations suitable for large scale use, much attention was devoted to finding a means of stimulating ovarian activity in farm animals. Ovulation was induced in a number of early studies in the pig using whole pituitary extracts (Casida, 1935 ; Tanabe et al., 1949 ; du Mesnil du Buisson, 1954 ; Spalding, Berry and Moffit, 1955), whereas preparations of human chorionic gonadotrophin (HCG) provided a source of luteinising hormone in more recent work on this species (Dziuk and Baker, 1962 ; Dziuk, Polge and Rowson, 1964 ; Dziuk and 
Polge, 1965 ; Hunter, 1967a). Treatments for inducing superovulatory responses with pregnant mares' serum gonadotrophin (PMSG) were described in the mid 1960's (Hunter, 1964, 1966 ; Longenecker, Lasley and Day, 1965), and a fechnique for synchronisation of ovulation in pigs using injections of PMSG and HCG as a sequel to a period of pituitary blockade has been presented (Polge, Day and Groves, 1968).

Much of the available literature on ovarian responses to gonadotrophin treatment in this species has been reviewed by Phillippo (1968), Anderson and Melampy (1972) and Dziuk (1973), but relatively little emphasis has been placed on the condition of the oocytes released by diverse gonadotrophic régimes. The intention of the present paper is to highlight certain observations on ovarian response, both published and unpublished, following treatment of mature pigs with serum and/or chorionic gonadotrophin, and to describe circumstances under which immature or defective eggs may be shed.

\section{Materials and methods.}

Detailed information concerning methodology has been presented in various papers referred to in the text, and will only be summarised here. Animals were crossbred Large White, usually Large White $\times$ Landrace, and weighed $90-145 \mathrm{~kg}$. They were checked for œstrous behaviour once or twice daily with a mature boar, and the first day of œstrus designated Day 0 ; ovulation would therefore generally occur on Day 1. Hormonal treatments were commenced on a specific day of the œstrous cycle, and involved subcutaneous injection of PMSG or intramuscular injection of HCG. The time of mating or the precise insemination treatment varied according to individual experiments. The observations that follow were all made at autopsy, even though in some instances eggs may have been flushed from the Fallopian fubes during midventral laparotomy.

Ovarian responses were judged macroscopically during the first few days after ovulation, although sectioning of luteal tissue was sometimes required in order to determine the number of developing corpora lutea. Eggs were prepared as whole mounts, fixed in 25 p. 100 acetic alcohol, stained with 0.5 p. 100 lacmoid or orcein in 45 p. 100 acetic acid, and examined by phase-contrast microscopy.

\section{Results and discussion.}

\section{Ovarian responses.}

Attempts to induce ovulation during the luteal phase of the cycle with a single injection of either PMSG or HCG were largely unsuccessful, irrespective of the dose of hormone employed. Thus, neither 1500 i.u. PMSG injected on Day 5 nor 500 i.u. HCG injected on Day 9 induced ovulation in the presence of the previously formed corpora lutea, although a single injection of HCG on Day 9 did provoke a slight response in three animals : one, two and three ovulations, respectively, were found at autopsy on Day 12. A successful protocol for inducing ovulation during the luteal phase consisted of 1500 i.u. PMSG injected on Day 5 followed by 500 i.u. HCG on 
Day 9 (Hunter, 1967b). An ovulatory response was invariably found on Day 11, although animals never exhibited cestrus and the number of induced ovulations varied very considerably (fig. 1).

FIG. 1. - Frequency distribution of the number of ovulations induced during the luteal phase of the cestrous cycle in 48 gilts. All animals were injected with 1500 i.u. PMSG on Day 5, 500 i.u. HCG on Day 9, and slaughtered on Day 11 or 12 of the cycle.

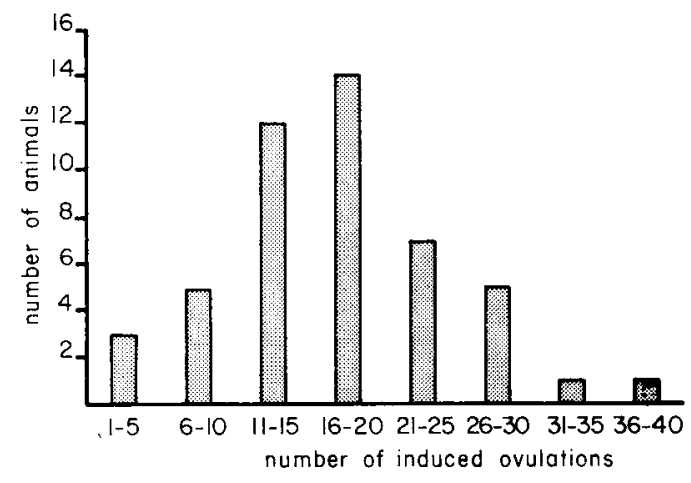

A mild degree of superovulation occurred in a majority of the 48 treated animals, but the mean ovarian response of 17.3 corpora lutea was approximately half that observed after treatment with 1,500 i.u. PMSG in the early follicular phase of the œstrous cycle (table 1). This is interpreted in part as a reflection of the number of Graafian follicles large enough to respond to treatment, but more importantly it may also reflect failure of endogenous gonadotrophic hormones to participate in ovarian stimulation following treatment in the luteal phase. The latter explanation clearly underlies the requirement for an ovulation-inducing injection of HCG on Day 9, even though Graafian follicles of mature diameter have formed in response to PMSG injection and are apparently synthesising œstrogens. This finding is in line with studies in other species, and accords with the conclusion of Hammond (1961) that follicles developed by PMSG in the presence of a corpus luteum do not in general ovulate spontaneously.

TABLE 1

Ovulatory responses to a single injection of 1,500 i. u. PMSG on different days of the oestrous cycle. Animals in the group treated with PMSG on Day 5 also received an injection of $500 \mathrm{i}$. U. HCG on Day 9

\begin{tabular}{cccc}
\hline \multirow{2}{*}{$\begin{array}{c}\text { Day of } \\
\text { treatment }\end{array}$} & $\begin{array}{c}\text { No. of } \\
\text { animals }\end{array}$ & \multicolumn{2}{c}{ Ovarian response } \\
\cline { 3 - 4 } & & mean & range \\
\hline 5 & 48 & 17.3 & $3-39$ \\
13 & 5 & 15.8 & $10-25$ \\
$14 *$ & 7 & 13.7 & $10-18$ \\
15 & 20 & 33.0 & $16-64$ \\
16 & 8 & 38.3 & $24-49$ \\
\hline
\end{tabular}

* This treatment led to abnormally prolonged cestrous cycles so the mean ovarian response may not be strictly comparable (see text). 
Details of the eggs released by gonadotrophin treatments are discussed below, but a characteristic of ovulations induced during the luteal phase is a low incidence of normal fertilisation (see Hunter, 1967b).

Treatment with PMSG in the late luteal phase produced a divergence of results between animals injected on Day 13 and those injected on Day 14. Four of five animals injected with 1,500 i.u. PMSG on Day 13 returned to œstrus between Days 18 and 20, and did not show a superovulatory response (table 1); the fifth animal exhibited œstrus on Day 26. In some contrast, none of seven gilts treated with 1,500 i.u. PMSG on Day 14 of the cycle returned to $œ$ strus in the succeeding twelve days. Two gilts came into oestrus on Day 27, two on Day 28, and two on Day 29 (Hunter, 1972a). The abnormal extension of the cycle after PMSG injection on Day 14 is thought to involve modification of the mechanism underlying luteal regression : disruption of the pattern of uterine prostaglandin secretion due to gonadotrophic stimulation of follicular œstrogens may be the principal factor here.

Superovulation was not found as a sequel to these Day 13 and Day 14 treatments, the mean ovarian responses being 15.8 and 13.7 , respectively (table 1). This is in marked contrast to the results of treatment one or two days later, and the difference in response cannot be explained by gross changes in the population of follicles. A failure of synergism between exogenous and endogenous hormones would again seem to be implicated. The question is therefore raised as to the means whereby injecting gonadotrophic hormones in the early follicular phase facilitates a release of endogenous gonadotrophins. Is there a positive feedback of gonadal steroids following treatment at this time (which may suggest a route for enhancing superovulatory responses), or is there also a component of central or hypophyseal stimulation by the injected hormone?

Superovulation follows a single injection of PMSG on Days 15 or 16 (fig. 2), and a response curve can be plotted for doses of hormone extending from 500-1,500 i.u. (Hunter, 1964). Apart from concluding that the early follicular phase was the best time to initiate superovulation, related studies noted that the ovarian response to PMSG diminished progressively when injections were given on Days 17 or 18 , and was extremely rarely augmented after a Day 19 injection, presumably due to a wave of follicular regression or atresia having commenced by this time (Hunter, 1972a). These observations correlate well with the incidence of ovarian compensatory hyper.
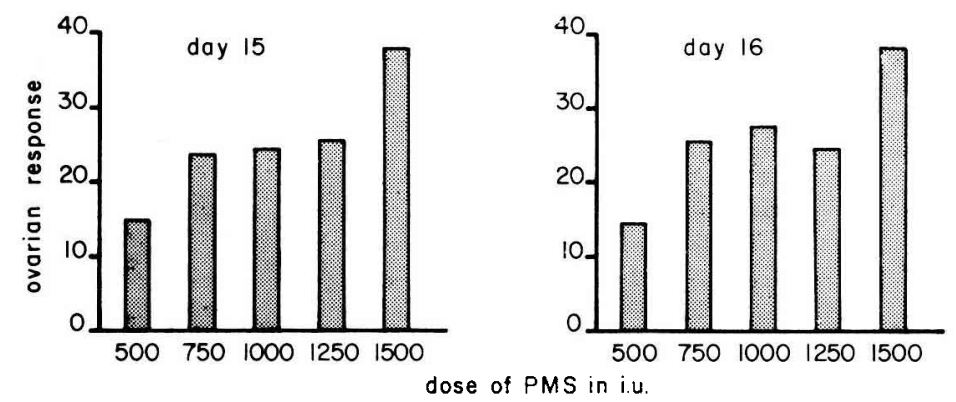

FIG. 2. - Ovarian response of gilts to injected gonadotrophin, representing the mean number of ovulations at each dose of PMSG according to the day of treatment during the oestrous cycle. 
trophy after unilateral ovariectomy performed at different times of the follicular phase (unpublished studies).

It has been reported elsewhere that a single injection of 500 or 1,000 i.u. HCG given late on Day 17 can induce mild superovulation (mean of 18.6 ovulations : Hunter, Cook and Baker, 1976), but treatment with chorionic gonadotrophin during the follicular phase is usually restricted to the period of mid to late pro-œstrus in order to regulate the time of ovulation (Dziuk ef al., 1964 ; Hunter, 1967a). This event occurs 40-42 hrs after a single injection of HCG, a finding in line with the observations of du Mesnil du Buisson (1954) using an anterior pituitary preparation.

\section{Morphological status of oocytes.}

An important difference between the population of oocytes shed in pigs after gonadotrophin treatment and that shed spontaneously during cstrus is the release of primary oocytes in the former situation. Such oocytes usually have an extremely compact investment of cumulus cells, and a large dictyate nucleus (germinal vesicle) situated close to the vitelline membrane. In this condition, they are considered as immature eggs, whereas those with a superficially similar nuclear morphology but devoid of any substantial cellular investment have been regarded as atretic. Some figures illustrating the incidence of primary oocyles are presented in table 2, from

TABLE 2

Observations drawn from a range of sources to show the incidence of primary oocytes ovulated in mature pigs

\begin{tabular}{|c|c|c|c|c|}
\hline \multirow{2}{*}{ Treatment } & \multirow{2}{*}{$\begin{array}{c}\text { Eggs } \\
\text { examined } \\
\text { No. }\end{array}$} & \multicolumn{2}{|c|}{$\begin{array}{l}\text { Primary } \\
\text { oocytes }\end{array}$} & \multirow{2}{*}{ Reference } \\
\hline & & No. & p. 100 & \\
\hline None. Spontaneous ovulation .... & 1677 & 3 & 0.2 & Hancock, 1961 \\
\hline $\begin{array}{c}\text { Gonadotrophins in follicular } \\
\text { phase..................... }\end{array}$ & 43 & 1 & 2.3 & Spalding et al., 1955 \\
\hline Provera followed by HCG & 1472 & 28 & 1.9 & Polge et Dziuk, 1965 \\
\hline Ovulation induced in luteal phase. & 325 & 14 & 4.3 & Hunter, $1967 b$ \\
\hline Superovulation in follicular phase. & 527 & 41 & 7.8 & Hunter, 1966 \\
\hline Premature ovulation ........... & 130 & 104 & 81.2 & Hunter et al., 1976 \\
\hline
\end{tabular}

which it will be noted that a superovulation treatment initiated on Day 15 of the cycle with a relatively high dose of PMSG leads to approximately 8 p. 100 of the eggs being shed in the immature condition. However, inspection of table 3 reveals that the ovarian response generally has to be in excess of 25-30, that is twice the spontaneous ovulation rate, before such eggs are commonly released. 


\section{TABLE 3}

The incidence of primary oocytes as a function of ovarian response to gonadotrophin treatment and in relation to the proportion of normally developing eggs (adapted from Hunter, 1966)

\begin{tabular}{ccc}
\hline $\begin{array}{c}\text { Corpora lutea } \\
\text { No. }\end{array}$ & $\begin{array}{c}\text { Primary oocytes } \\
\text { No. }\end{array}$ & $\begin{array}{c}\text { Eggs developing } \\
\text { normally } \\
\text { p. } 100\end{array}$ \\
\hline 64 & 13 & 70.4 \\
61 & 8 & 63.2 \\
52 & 7 & 71.3 \\
45 & 1 & 93.3 \\
35 & 3 & 80.0 \\
32 & 1 & 86.7 \\
31 & 2 & 82.1 \\
31 & 1 & 93.3 \\
26 & 2 & 92.0 \\
25 & 1 & 95.8 \\
24 & 1 & 95.8 \\
21 & 1 & 90.0 \\
& & \\
\hline
\end{tabular}

At some variance with these findings, a single injection of either 500 or 1,000 i.u. HCG late on Day 17 leads to the release of predominantly primary oocytes (Hunter et al., 1976), even though the ovarian response represents only a mild degree of superovulation. An essential difference to be considered when trying to reconcile these two observations is that ovulation occurs within two days of the Day 17 HCG treatment and the animals never exhibil œestrus whereas it occurs four to five days after Day 15 PMSG treatment during a characteristic œstrus.

These findings would appear to stress the value of a normal period of follicular maturation permitting growth to the terminal size of Graafian follicle (9-11 $\mathrm{mm}$ diameter in gilts) and consequently overt œstrus, and may suggest that treatments provoking ovulation in a shortened follicular phase run the risk of releasing incompletely matured oocytes. An interpretation for the rôle of increasing concentrations of follicular œstrogens in mediating various aspects of oocyte maturation in pigs has been put forward elsewhere (Hunter ef al., 1976). Furthermore, the reasoning for an involvement of œstrogens was extended from the ovarian level to that of physiological responses in the whole animal where an integrating gonadal hormone is needed during the late follicular phase to co-ordinate changes within the follicle, the reproductive tract and the hypothalamo-pituitary axis.

An explanation for the shedding of primary oocytes following gonadotrophin treatment during the luteal phase (table 2) probably lies in the extent of the ovarian response, or perhaps size of follicle, rather than in the interval between stimulation and ovulation. The protocol permitted four days for follicular growth in response to PMSG before imposing the ovulating injection of HCG. Inspection of individual responses reveals that primary oocytes were shed in luteal phase animals only when the number of ovulations exceeded 23, three primary oocytes being recovered from one gilt with a total of 39 recent ovulations. Nonetheless, this apparent correlation between ovarian response and incidence of primary oocytes does not indicate the precise 
reason for failure of maturation, nor whether the size of follicle releasing such an oocyte is the primary factor involved.

As to previous observations on the shedding of primary oocytes in pigs (table 2), Spalding ef al. (1955) were the first to record this condition using a suitable staining technique, and suggested that the injected gonadotrophins stimulated follicular growth and ovulation, but failed to stimulate the physiological trigger mechanism for oocyte maturation. Polge and Dziuk (1965) reported a much increased incidence of primary oocytes after inducing ovulation as a sequel to pituitary blockade with oral progestagens, and suggested that these eggs were released from follicles insufficiently mature either to transmit a stimulus to the oocyte or to permit removal of a meiotic inhibitor. But they also considered the possibility that the oocytes might in some way be defective, since nuclear maturation was not resumed even after periods of up to $18 \mathrm{hrs}$ in the Fallopian tubes.

\section{Physiological status of oocytes.}

Concerning the fertilisability of oocytes released after gonadotrophin treatment in animals mated or artificially inseminated some hours before ovulation, the incidence of normal fertilisation varies with the stage of the cycle and according to the ovarian response. Thus, the proportion of eggs undergoing normal fertilisation after artificial insemination during the luteal phase was only 32 p. 100 (Hunter, 1967b), whereas it was usually in excess of 90 p. 100 in the follicular phase if the response to treatment was not greater than some 30 ovulations (Hunter, 1964, 1966) ; thereafter, it diminished significantly (table 3), but principally on account of primary oocytes.

Primary oocytes invariably underwent polyspermic penetration, the numbers of spermatozod entering the vitellus of individual eggs ranging from 2 to $>80$ (Polge and Dziuk, 1965 ; Hunter, $1967 b$; Hunter et al., 1976). Normal male pronuclear formation was not detected in oocytes at the dictyate stage, nor was swelling of the sperm heads far advanced when examined by phase-contrast microscopy. Nonetheless, slight decondensation of the sperm nucleus could be observed in a small proportion of the oocytes, and separation of the mid-piece from the sperm head was sometimes detected. Whilst these observations on porcine primary oocytes clearly indicate a failure of both nuclear and cytoplasmic maturation, there was no suggestion of any failure of membranous maturation in terms of the ability of spermatozoa to bind to the egg surface before penetration. The latter has been reported to be another component of oocyte maturation, as expressed in the development of receptor sites for spermatozoa on the zona pellucida of hamster oocytes (Plachot and Mandelbaum, 1978).

Polyspermy in porcine primary oocytes was considered by Polge and Dziuk (1965) to be due to continued penetrability of the egg membranes, and Dziuk and Dickmann (1965) further suggested that the block to polyspermy develops concomitantly with meiotic maturation. A more detailed explanation of this phenomenon would invoke a role for the cortical granules (Szöllösi, 1962, 1967 ; Fléchon, 1970), which may not have migrated to their final location just beneath the vitelline membrane and hence would be unable to undergo fusion with the plasmalemma in order to discharge their contents. In other words, terminal migration of the cortical granules must be seen as an essential functional aspect of oocyte maturation (see Szöllösi et al., 1978). 
An incomplete swelling and evolution of the sperm head within the vitellus has been discussed previously (Austin, 1961 ; Hunter, 1967b ; Thibault and Gérard, 1970), and may concern cytoplasmic components present in only limited amounts or even unavailable in primary oocytes. Absence of a male pronucleus growth factor (MPGF) has been demonstrated in in vitro matured rabbit oocytes (Thibault and Gérard, 1970), and the evolution of such an MPGF has been analysed in both rabbit and calf oocytes (Thibault, Gérard and Ménézo, 1975). This component of cytoplasmic maturation may well bear a close relationship to some of the specific proteins appearing in the vitellus during maturation, as elegantly demonstrated in sheep oocytes (Moor and Warnes, 1978).

Apart from the phenomenon of extensive polyspermy in primary oocytes, other studies have indicated that a reasonably constant proportion of secondary oocytes (20-35 p. 100) can also be induced to undergo this form of abnormal fertilisation in

TABLE 4

The incidence of polyspermic fertilisation exhibited in mature pigs in various experimental situations after mating or insemination at the time of ostrus

\begin{tabular}{|c|c|c|c|c|}
\hline Treatment & $\begin{array}{c}\text { Eggs } \\
\text { examined } \\
\text { No. }\end{array}$ & & $\begin{array}{l}\text { ermic } \\
\text { ps } 100\end{array}$ & Reference \\
\hline Delayed mating & 53 & 6 & $11.0 *$ & Thibault, 1959 \\
\hline Delayed mating & 41 & 12 & 29.2 & Hancock, 1959 \\
\hline Delayed insemination & 149 & 23 & 15.4 & Hunter, $1967 c$ \\
\hline Tubal surgery & 34 & 11 & 32.4 & $\begin{array}{l}\text { Hunter and Léglise, } \\
1971\end{array}$ \\
\hline Progesterone micro-injections .. & 198 & 64 & 32.3 & Hunter, $1972 b$ \\
\hline Tubal insemination & 77 & 26 & 33.8 & Hunter, 1973 \\
\hline
\end{tabular}

* A further 21 p. 100 of the eggs were considered digynic.

several experimental situations (table 4), figures that correspond quite closely to the usual incidence of embryonic mortality. The question therefore arises as to whether susceptibility to polyspermy in apparently mature eggs under specified experimental conditions may be a means of demonstrating some degree of physiological incompetence, and whether techniques of this nature can reveal those eggs destined to undergo early embryonic death. If there is any validity in this argument, it will require the application of sensitive test systems and not those involving pharmacological doses of progesterone (Day and Polge, 1968) or insemination directly into the Fallopian tubes (Hunter, 1976), both of which treatments may lead to a very high incidence of polyspermy. 
Acknowledgements. - Studies of the author referred to in this paper were supported by grants from the Agricultural Research Council (UK) and Ford Foundation (USA), for which grateful acknowledgement is made.

Résumé. L'influence sur le déroulement du cycle estrien ef le taux d'ovulation de l'injection de PMSG et/ou de HCG a été étudiée pendant la phase lutéale et pendant la phase folliculaire du cycle chez la Truie.

Après une injection de $1500 \mathrm{UI}$ d'HCG au 13e jour, l'estrus se produit dans les 5 à 7 jours suivants. L'injection de 1500 IU de PMSG entraîne des réponses variables selon le moment du cycle. En fin de phase lutéale, au 14e jour, l'injection de PMSG retarde l'apparition de l'estrus jusqu'au $27^{\mathrm{e}}-29$ e jour chez les 6 truies traitées. Le début de la « phase folliculaire » (15e et 16e jours) doit être considéré comme le moment optimum pour induire une superovulation. L'injection aux jours 17, 18 ou 19 raccourcit légèrement la durée du cycle et provoque une superovulation seulement chez quelques animaux. Ces observations s'accordent bien avec la possibilité d'induire une réaction compensatrice de l'ovaire restant après hémicastration effectuée d̀ différents moments de la phase folliculaire.

Une faible proportion d'ovocytes $(<10$ p. 100) sont pondus à l'état dictyé, quand la superovulation résulte de l'injection de PMSG au jour 15 ou 16 et également lorsque l'ovulation est induite en phase lutéale, tandis que 80 p. 100 des ovocytes sont pondus après injection d'HCG au jour 17. De tels ovocytes subissent toujours une pénétration polyspermique après insémination artificielle. Une proportion relativement importante d'ovocytes secondaires (20-35 p. 100) peuvent aussi montrer ce type de fécondation anormale dans différentes conditions expérimentales. Ceci suggère que la susceptibilité d'ovocytes apparemment mûrs vis-à-vis de la polyspermie peut être un moyen de révéler une incapacité physiologique de l'ovocyte. De tels œufs sont destinés à une mort embryonnaire précoce.

\section{References}

ANDERSON L. L., MELAMPY R. M., 1972. Factors affecting ovulation rate in the pig, 329-366. In COLE D. J. A., Pig Production, Butterworihs, London.

AUSTIN C. R., 1961. The Mammalian Egg, Blackwell, Oxford.

CASIDA L. E., 1935. Prepuberal development of the pig ovary and its relation to stimulation with gonadotrophic hormones. Anat. Rec., 61, 389-396.

DAY B. N., POLGE C., 1968. Effects of progesterone on fertilization and egg transport in the pig. J. Reprod. Fert., 17, 227-230.

DU MESNIL DU BUISSON F., 1954. Possibilité d'ovulation ef de fécondation chez la truie avant la puberté. Ann. Endocr. (Paris), 15, 333-340.

DZIUK P. J., 1973. Occurrence, control and induction of ovulation in pigs, sheep and cows. In GREEP R. O., Handbook of Physiology, Section 7, Vol. 2, 143-152, Am. Physiol. Soc.

DZIUK P. J., BAKER R. D., 1962. Induction and control of ovulation in swine. J. Anim. Sci., 21, 697699.

DZIUK P. J., DICKMANN Z., 1965. Failure of the zona reaction in five pig eggs. Nature (London), 208, 502-503.

DZIUK P. J., POLGE C., 1965. Fertility in gilts following induced ovulation. Vet. Rec., 77, 236-239.

DZIUK P. J., POLGE C., ROWSON L. E. A., 1964. Intra-uterine migration and mixing of embryos in swine following egg transfer. J. Anim. Sci., 23, 37-42.

FLÉCHON J. E., 1970. Nature glycoprotéique des granules corticaux de l'œuf de lapine. J. Microscop., 9, $221-242$.

HAMMOND J. Jr., 1961. Hormonal augmentation of fertility in sheep and cattle. 163-176. In VILLEE C. A., Control of Ovulation, Pergamon, London.

HANCOCK J. L., 1959. Polyspermy of pig ova. Anim. Prod., 1, 103-106.

HANCOCK J. L., 1961 . Fertilization in the pig. J. Reprod. Fert., 2, 307-331.

HUNTER R. H. F., 1964. Superovulation and fertility in the pig. Anim. Prod., 6, 189-194. 
HUNTER R. H. F., 1966. The effect of superovulation on fertilisation and embryonic survival in the pig. Anim. Prod., 8, 457-465.

HUNTER R. H. F., 1967a. Porcine ovulation after injection of human chorionic gonadotrophin. Vet. Rec., 81, 21-23.

HUNTER R. H. F., 1967b. Polyspermic fertilisation in pigs during the luteal phase of the ostrous cycle. J. exp. Zool., 165, 451-460.

HUNTER R. H. F., 1967c. The effects of delayed insemination on fertilisation and early cleavage in the pig. J. Reprod. Fert., 13, 133-147.

HUNTER R. H. F., 1972a. Ovarian response of the pig to gonadotrophins injected at different stages of the œstrous cycle. Proc. 7th int. Congr. Anim. Reprod., Munich, 2, 1053-1057.

HUNTER R. H. F., 1972b. Local action of progesterone leading to polyspermic fertilisation in pigs. J. Reprod. Fert., 31, 433-444.

HUNTER R. H. F., 1973. Polyspermic fertilisation in pigs after tubal deposition of excessive numbers of spermatozoa. J. exp. Zool., 183, 57-64.

HUNTER R. H. F., 1976. Sperm-egg interactions in the pig : monospermy, extensive polyspermy, and the formation of chromatin aggregates. J. Anat., 122, 43-59.

HUNTER R. H. F., COOK B., BAKER T. G., 1976. Dissociation of response to injected gonadotropin between the Graafian follicle and oocyte in pigs. Nature (London), 260,156-158.

HUNTER R. H. F., LÉGLISE P. C., 1971. Polyspermic fertilisation following tubal surgery in pigs, with particular reference to the rôle of the isthmus. J. Reprod. Fert., 24, 233-246.

LONGENECKER D. E., LASLEY J. F., DAY B. N., 1965. Fecundity in gilts and sows administered PMS. J. Anim. Sci., 24, 924.

MOOR R. M., WARNES G. M., 1978. Regulation of oocyte maturation in mammals, 159-176. In CRIGHTON D. B., HAYNES N. B., FOXCROFT G. R., LAMMING G. E., Control of ovulation. Butterworths, London.

PHILLIPPO M., 1968. Superovulation in the pig. Adv. Reprod. Physiol., 3, 147-166.

PLACHOT M., MANDELBAUM J., 1978. Comparative study of extra and intrafollicular hamster oocyte maturation. Ann. Biol. anim. Bioch. Biophys., 18, 1237-1246.

POLGE C., DAY B. N., GROVES T. W., 1968. Synchronisation of ovulation and artificial insemination in pigs. Vet. Rec., 83, 136-142.

POLGE C., DZIUK P., 1965. Recovery of immature eggs penetrated by spermatozoa following induced ovulation in the pig. J. Reprod. Fert., 9, 357-358.

SPALDING J. F., BERRY R. O., MOFFIT J. G., 1955. The maturation process of the ovum of swine during normal and induced ovulations. J. Anim. Sci., 14, 609-620.

SZÖLLÖSI D., 1962. Cortical granules : a general feature of mammalian eggs ? J. Reprod. Fert., 4, 223-224.

SZÖLLÖSI D., 1967. Development of cortical granules and the cortical reaction in rat and hamster eggs. Anat. Rec., 159, 431-446.

SZÖLLÖSI D., GÉRARD M., MÉNÉZO Y., THIBAULT C., 1978. Permeability of ovarian follicle ; corona cell-oocyte relationship in mammals. Ann. Biol. anim. Bioch. Biophys., 18, 511-521.

TANABE T. Y., WARNICK A. C., CASIDA L. E., GRUMMER R. H., 1949. The effects of gonadotropins administered to sows and gilts during different stages of the estrual cycle. J. Anim. Sci., 8, 550-557.

THIBAULT C., 1959. Analyse de la fécondation de l'œuf de la truie après accouplement ou insémination artificielle. Ann. Zootech. D, Suppl. 165-177.

THIBAULT C., GÉRARD M., 1970. Facteur cytoplasmique nécessaire à la formation du pronucleus mâle dans l'ovocyte de lapine. C. R. Acad. Sci. Paris, sér. D., 270, 2025-2026.

THIBAULT C., GÉRARD M., MÉNÉZZ Y., 1975. Acquisition par l'ovocyte de lapine et de veau du facteur de décondensation du noyau du spermatozoïde fécondant (MPGF). Ann. Biol. anim. Bioch. Biophys., 15, 705-714. 